\title{
UNIVERSITY OF LUND RADIOCARBON DATES XIV
}

SÖREN HAKANSSON

Radiocarbon Dating Laboratory, Department of Quaternary Geology University of Lund, Sweden

\section{INTRODUCTION}

Most of the ${ }^{14} \mathrm{C}$ measurements reported here were made between October 1979 and October 1980. Equipment, measurement, and treatment of samples are as reported previously $(\mathrm{R}, 1968$, v 10, p 36-37; 1976, v 18, p 290; 1980, v 22, p 1045).

Age calculations are based on a contemporary value equal to $95 \%$ of the activity of NBS oxalic acid standard and on the conventional half-life for ${ }^{14} \mathrm{C}$ of $5568 \mathrm{yr}$. Results are reported in years before 1950 (years BP). Errors quoted $( \pm 1 \sigma)$ include standard deviations of count rates for the unknown sample, contemporary standard, and background.

Corrections for deviations from $\delta^{13} \mathrm{C}=-25.0 \%$ in the PDB scale are applied for all samples; also for marine shells and other carbonate samples. The apparent age for marine material due to the reservoir effect must be subtracted from our dates on such samples.

The remark "undersized; diluted", in Comments means the sample did not produce enough $\mathrm{CO}_{2}$ to fill the counter to normal pressure and "dead" $\mathrm{CO}_{2}$ from authracite was introduced to make up the pressure. "\% sample" indicates amount of $\mathrm{CO}_{2}$ derived from the sample present in the diluted counting gas; the rest is "dead" $\mathrm{CO}_{2}$. Organic carbon content reported for bone samples is calculated from yield of $\mathrm{CO}_{2}$ by combustion of gelatine remaining after treatment. Organic carbon lost during treatment is not included in calculated percentage.

The description of each sample is based on information provided by the submitter.

\section{ACKNOWLEDGMENTS}

The author thanks Kerstin Lundahl for sample preparation and routine operation of the dating equipment, and $\mathrm{R}$ Ryhage and his staff at the mass-spectrometric laboratory of Karolinska Inst, Stockholm, for the ${ }^{13} \mathrm{C}$ analyses.

\section{SAMPLE DESCRIPTIONS}

I. GEOLOGIC SAMPLES

A. Sweden

\section{Abisko series (II)}

Sediment from Lake Tjåutjanjaure (68 $\left.18^{\circ} \mathrm{N}, 18^{\circ} 33^{\prime} \mathrm{E}\right)$ and from nameless small lake at $458 \mathrm{~m}$ alt $\left(68^{\circ} 29^{\prime} \mathrm{N}, 18^{\circ} 17^{\prime} \mathrm{E}\right)$ in Abisko area, N Sweden. Coll 1978 by M Hjelmroos and G Digerfeldt; subm by M Hjelmroos, Dept Quaternary Geol, Univ Lund. Dating is part of palaeoecologic study, belonging to IGCP Subproject 158B (Berglund, 1979), of postglacial vegetational history in area. For other dates from area, see Abisko series (I) (R, 1980, v 22, p 1045-1047). Depths given are below water surface. All samples pretreated with $\mathrm{HCl}$. 
Lu-1657. Tjåutjanjaure 1, 720 to $725 \mathrm{~cm}$ Algal gyttja.

Lu-1658. Tjåutjanjaure 2,670 to $675 \mathrm{~cm}$ Algal gyttja.

Lu-1659. Tjåutjanjaure 3, 620 to $625 \mathrm{~cm}$ Algal gyttja.

Lu-1660. Tjåutjanjaure 4, 570 to $575 \mathrm{~cm}$ Algal gyttja.

Lu-1661. Tjåutjanjaure 5, 520 to $525 \mathrm{~cm}$ Algal gyttja.

Lu-1662. Tjåut janjaure 6, 470 to $475 \mathrm{~cm}$ Algal gyttja.

Lu-1663. Tjåutjanjaure 7, 420 to $425 \mathrm{~cm}$ Algal gyttja.

Lu-1664. Tjåutjanjaure 8, 370 to $375 \mathrm{~cm}$ Loose sediment.

Lu-1665. Tjåutjanjaure 9, 320 to $325 \mathrm{~cm}$ Loose surface sediment.

Lu-1666. Lake 458:1, 1175 to $1180 \mathrm{~cm}$

Clayey and sandy fine detritus gyttja. Comment: sample undersized; diluted; $73 \%$ sample.

Lu-1667. Lake $458: 2,1160$ to $1165 \mathrm{~cm}$ Sandy fine detritus gyttja.

Lu-1668. Lake 458:3, 1125 to $1130 \mathrm{~cm}$ Silty fine detritus gyttja. $\mathbf{8 8 4 0} \pm \mathbf{8 5}$

$\delta^{13} C=-24.6 \%$

$7710 \pm 75$

$\delta^{13} C=-20.7 \%$

$$
\begin{array}{r}
6650 \pm 70 \\
\delta^{13} C=-24.3 \% 0
\end{array}
$$

$5390 \pm 65$ $\delta^{13} C=-20.2 \%$

$$
4500 \pm 60
$$$$
\delta^{13} \mathrm{C}=-23.8 \%
$$

$$
4010 \pm 60
$$$$
\delta^{13} \mathrm{C}=-23.1 \%
$$

$$
\mathbf{3 3 0 0} \pm \mathbf{5 5}
$$$$
\delta^{1 s} C=-21.9 \%
$$

$$
\begin{array}{r}
\mathbf{1 5 5 0} \pm \mathbf{5 0} \\
\delta^{13} C=-21.3 \% 0
\end{array}
$$

$$
\begin{array}{r}
\mathbf{8 6 0} \pm \mathbf{5 0} \\
\delta^{1 s} C=-22.0 \%
\end{array}
$$

$$
7880 \pm 100
$$

$\delta^{13} C=-24.3 \%$

\section{Olsäng series (II)}

Peat from area with beach ridges (Mikaelsson, 1978) at Olsäng, SE Blekinge $\left(56^{\circ} 12^{\prime} \mathrm{N}, 15^{\circ} 59^{\prime} \mathrm{E}\right)$. Coll 1979 by Jan Mikaelsson and C G Holdar; subm by Jan Mikaelsson, Dept Quaternary Geol, Univ Lund. Dated as complement to Olsäng series (R, 1979, v 21, p 386). All samples pretreated with $\mathrm{HCl}$. 


\section{Lu-1736. Olsäng 1979:1}

$5030 \pm 65$

Sandy peat.

\section{Lu-1737. Olsäng 1979:2}

Peat mixed with eolian sand $1 \mathrm{~m}$ below surface.

Lu-1738. Olsäng 1979:3

$$
\delta^{13} C=-25.5 \% \text { 。 }
$$

$$
\begin{array}{r}
160 \pm 45 \\
\delta^{13} C=-24.6 \% 0
\end{array}
$$

Lowest part of brushwood peat underlain by eolian sand $90 \mathrm{~cm}$ below surface.

\section{Hunneberg series (II)}

Sediment from lakes Bergsjön ( $\left.58^{\circ} 18^{\prime} \mathrm{N}, 12^{\circ} 26^{\prime} \mathrm{E}\right)$, Långvattnet $\left(58^{\circ} 20^{\prime} \mathrm{N}, 12^{\circ} 27^{\prime} \mathrm{E}\right)$, Svartevattnet $\left(58^{\circ} 18^{\prime} \mathrm{N}, 12^{\circ} 29^{\prime} \mathrm{E}\right)$, Kroppsjön $\left(58^{\circ} 19^{\prime} \mathrm{N}, 12^{\circ} 26^{\prime} \mathrm{E}\right)$, Alsjön $\left(58^{\circ} 18^{\prime} \mathrm{N}, 12^{\circ} 30^{\prime} \mathrm{E}\right)$, Ekelunds Gransjö $\left(58^{\circ} 19^{\prime} \mathrm{N}, 12^{\circ} 26^{\prime} \mathrm{E}\right)$, Grinnsjön $\left(58^{\circ} 18^{\prime} \mathrm{N}, 12^{\circ} 27^{\prime} \mathrm{E}\right)$, and Stubbsjön $\left(58^{\circ} 21^{\prime} \mathrm{N}, 12^{\circ} 26^{\prime} \mathrm{E}\right)$ on hill Hunneberg, NW Västergötland. Coll 1977 and subm by $\mathrm{G}$ Digerfeldt, Dept Quaternary Geol, Univ Lund. Dating is part of study of Late Weichselian shore-line displacement in area. Isolation of lakes established by diatom analysis. For other dates from area, see Hunneberg series ( $R, 1977, v 19$, p 425-427). Depths refer to sediment surface. All samples pretreated with $\mathrm{HCl}$.

\section{Bergsjön}

Lu-1763. Bergsjön, 485 to $490 \mathrm{~cm}$

Clay gyttja 15 to $20 \mathrm{~cm}$ above isolation level.

\section{Långvattnet}

Lu-1764. Långvattnet, Core I, 275 to $280 \mathrm{~cm}$

Clay gyttja 20 to $25 \mathrm{~cm}$ above isolation level.

Lu-1765. Långvattnet, Core II, 280 to $285 \mathrm{~cm}$

Clay gyttja just above isolation level.

\section{Svartevattnet}

Lu-1766. Svartevattnet, 427 to $432 \mathrm{~cm}$

Clay gyttja just above isolation level.

\section{Kroppsjön}

Lu-1767. Kroppsjön, 634 to $639 \mathrm{~cm}$

Clay gyttja just above isolation level.

$$
\begin{array}{r}
9910 \pm 90 \\
\delta^{13} C=-25.0 \%
\end{array}
$$

$$
\begin{array}{r}
9740 \pm 90 \\
\delta^{13} C=-24.7 \% \text { o }
\end{array}
$$

$10,020 \pm 95$ $\delta^{1 s} C=-23.2 \%$

$$
10,730 \pm 100
$$$$
\delta^{13} C=-20.6 \% \text { 。 }
$$

$11,390 \pm 105$ $\delta^{13} C=-18.3 \%$ 
Alsjön

Lu-1768. Alsjön, 245 to $250 \mathrm{~cm}$

Clay gyttja just above isolation level.

\section{Ekelunds Gransjö}

Lu-1769. Ekelunds Gransjö, Core I, 365 to $370 \mathrm{~cm}$

Clay gyttja just above isolation level.

Lu-1770. Ekelunds Gransjö, Core II, 610 to $615 \mathrm{~cm}$

Clay gyttja just above isolation level.

\section{Grinnsjön}

Lu-1771. Grinnsjön, 305 to $310 \mathrm{~cm}$

Clay gyttja 10 to $15 \mathrm{~cm}$ above isolation level.

\section{Stubbsjön}

Lu-1772. Stubbsjön, Core I, 592 to $596.5 \mathrm{~cm}$

Clay gyttja just above isolation level.

Lu-1773. Stubbsjön, Core II, 564 to $567 \mathrm{~cm}$

Muddy clay 5 to $10 \mathrm{~cm}$ above isolation level. Comment: sample undersized; diluted; $61 \%$ sample.

\section{Billingen series}

Sediment from Lake Vallersjön $\left(58^{\circ} 28^{\prime} \mathrm{N}, 13^{\circ} 48^{\prime} \mathrm{E}\right)$ on hill Billingen, E Västergötland. Coll 1977 and subm by G Digerfeldt. Deglaciation of area was studied. Depths refer to sediment surface. For other dates from Billingen, see Bjärsjön series (R, 1980, v 22, p 1047-1048).

\section{Lu-1774. Vallersjön, Core I, 462 to $466 \mathrm{~cm}$}

Clay gyttja. Comment: pretreated with $\mathrm{HCl}$.

\section{Lu-1775. Vallersjön, Core II, 448 to $452 \mathrm{~cm}$}

$$
\begin{array}{r}
9150 \pm 90 \\
\delta^{13} C=-28.8 \% \circ
\end{array}
$$

Gyttja. Comment: no pretreatment; small sample; burned at $<650^{\circ} \mathrm{C}$ to avoid pyrolysis of carbonate.

\section{Lu-1706. Rörerum, Balanids, inner fraction}

$$
\begin{array}{r}
\mathbf{8 3 9 0} \pm \mathbf{8 0} \\
\delta^{13} \mathrm{C}=-3.6 \%
\end{array}
$$

Small balanid shells found in situ on large boulder at surface of glacio-fluvial deposit at Rörerum, Dalsland ( $\left.58^{\circ} 37^{\prime} 20^{\prime \prime} \mathrm{N}, 12^{\circ} 04^{\prime} 40^{\prime \prime} \mathrm{E}\right)$. Coll 1979 and subm by $\AA$ Hillefors, Dept Phys Geog, Univ Lund. Comments: inner fraction $(71 \%$ of shells) was used. $(\AA \mathrm{H})$ : date younger than expected. 


\section{Lu-1707. Rörerum, Balanids, outer fraction}

Outer fraction of shells used for Lu-1706. Comment: outer fraction was $21 \%$ of sample. Shells contained some silt firmly connected with inner shell surfaces. Silt was slightly calcareous which was probably reason for higher age of outer fraction.

\section{Lummelunda Cave series (II)}

Precipitated calcite from Lummelunda Cave, N Gotland $\left(57^{\circ} 44^{\prime} 13^{\prime \prime}\right.$ N, $18^{\circ} 24^{\prime} 45^{\prime \prime}$ E). Coll 1978 and subm by L Engh, Dept Phys Geog, Univ Lund. Dated as part of study of chronology of cave deposits. For other dates from this cave, see R, 1979, v 21, p 392.

\section{Lu-1700. Lummelunda Cave, Sample 1:1978 $\delta^{13} C=-5.0 \%$} Porous calcite precipitated on cave ceiling.

1701. $1300 \pm 50$

Lu-1701. Lummelunda Cave, Sample 2:1978 $\quad \delta^{1 s} C=-7.1 \%$

Horizontal travertine layer from Mailbox Hall, overlain by gyttja and fine-grained sediments, and underlain by fine-grained sediments alternating with travertine layers.

Lu-1702. Lummelunda Cave, Sample 3:1978 $\quad \begin{array}{rr}\mathbf{3 5 7 0} \pm \mathbf{5 5} \\ \delta^{13} C=-6.9 \%\end{array}$

Horizontal travertine layer from Mailbox Hall, overlain by 5 other travertine layers alternating with fine-grained sediments.

General Comment: radiocarbon ages for calcite samples are calculated in same way as for organic samples since initial activity at time of precipitation is unknown.

\section{Labyrint Cave series}

Travertine from Labyrint Cave on V slope of Mt Miesket, $S$ of Lake Över-Uman in Tärnaby $\mathrm{Mt}$ area $\left(66^{\circ} 04^{\prime} 10^{\prime \prime} \mathrm{N}, 14^{\circ} 04^{\prime} \mathrm{E}\right)$. Dated as part of same study as Lummelunda Cave series, above. Coll 1977-1978 and subm by L Engh.

Lu-1704. Labyrint Cave, Sample 5:1977

$18,480 \pm 220$ luted; $85 \%$ sample.

Lu-1705. Labyrint Cave, Sample 6:1977

$11,810 \pm 160$

Lower part of travertine layer. Comment: sample undersized; luted; $55 \%$ sample.

Lu-1836. Labyrint Cave, Sample A:1978

$17,600 \pm 160$

Upper part of travertine layer. Comment: (3 1-day counts.) 


\section{Lu-1837. Labyrint Cave, Sample B : 1978}

$11,410 \pm 105$

Lower part of travertine layer.

General Comment: radiocarbon ages are calculated in same way as Lummelunda Cave series, above.

\section{Lu-1703. Helgeandsholmen, stalagmite}

$\mathbf{2 1 4 0} \pm \mathbf{5 0}$

Lowest 3 to $5 \mathrm{~mm}$ of stalagmite precipitated on wooden plank at bottom of sewer canal (Flemmings kanal) built ca AD 1650 on Helgeandsholmen, Central Stockholm (59 $\left.25^{\prime} \mathrm{N}, 18^{\circ} 00^{\prime} \mathrm{E}\right)$. Coll 1978 by L E Åström; subm by L Engh. Comment: according to measurements by Stuiver (1978, p 271), a sample from AD 1650 will give a radiocarbon age of between 225 and $255 \mathrm{yr}$ BP. Calculation based on $240 \mathrm{yr}$ gives, as a result, that 2140 BP corresponds to an initial activity at time of precipitation of ca $79 \%$ modern (modern activity $=95 \%$ of $\mathrm{NBS}$ oxalic acid standard activity in 1950).

\section{Kärkevagge series}

Grass and moss turf from solifluction lobe at Kärkevagge (ca $68^{\circ} 23^{\prime}$ N, $18^{\circ} 21^{\prime} \mathrm{E}$ ), N Sweden. Coll 1978 by J Akerman; subm by A Rapp and J Åkerman, Dept Phys Geog, Univ Lund.

\section{Lu-1719. Kärkevagge, Sample I}

Grass and moss turf, $1 \mathrm{~m}$ below lobe surface.

\section{Lu-1720. Kärkevagge, Sample II}

Grass and moss turf, Im below lobe surface.

Lu-1721. Kärkevagge, Sample III

Moss turf, $0.5 \mathrm{~m}$ below lobe surface.

\section{Holmfjeldvand series}

\section{B. Norway}

Sediment from Lake Holmfjeldvand, Varanger Peninsula, $\mathrm{N}$ Norway $\left(70^{\circ} 13^{\prime} 45^{\prime \prime} \mathrm{N}, 30^{\circ} 18^{\prime} \mathrm{E}\right)$. Dated as complement to Varanger Peninsula series (R, 1974, v 16, p 317-318; 1978, v 20, p 422-423). Coll 1976 and subm by B Malmström and O Palmér, Dept Phys Geog, Univ Lund. No pretreatment; small samples; burned at $<650^{\circ} \mathrm{C}$ to avoid carbonate pyrolysis and graphite oxidation. Depths are below sediment surface.

Lu-1727. Holmfjeldvand IVa, 295 to $300 \mathrm{~cm}$ Muddy clay.

Lu-1728. Holmfjeldvand IVa, 236 to $241 \mathrm{~cm}$ Clayey gyttja.
$10,240 \pm 95$

$\delta^{13} \mathrm{C}=-19.9 \%$

$$
8120 \pm 80
$$

$\delta^{13} \mathrm{C}=-23.8 \%$ o 


\section{Lu-1722. Kapp Linné}

Grass and moss turf, $40 \mathrm{~cm}$ below surface of small palsa at Kapp Linné, Spitsbergen $\left(78^{\circ} 03^{\prime} \mathrm{N}, 14^{\circ} 35^{\prime} \mathrm{E}\right)$. Coll 1972 by J Åkerman; subm by A Rapp and J Akerman. Pretreated with HCl. Burned at < $650^{\circ} \mathrm{C}$ to avoid graphite oxidation.

\section{Iceland}

\section{Lu-1735. Nykurtjörn}

$$
\begin{array}{r}
6870 \pm 95 \\
\delta^{1 s} C=-17.9 \% o
\end{array}
$$

Silty fine detritus gyttja from 388 to $393 \mathrm{~cm}$ below sediment surface in Nykurtjörn, Í Fjördum, Central N Iceland $\left(66^{\circ} 10^{\prime} 41^{\prime \prime} \mathrm{N}, 18^{\circ} 05^{\prime}\right.$ $53^{\prime \prime}$ W). Alt ca $140 \mathrm{~m}$. Coll 1978 by M Hallsdóttir and H Nordahl; subm by $\mathrm{H}$ Nordahl, Dept Quaternary Geol, Univ Lund. Pretreated with HCl. Sample undersized; diluted; $64 \%$ sample.

\section{North Greenland Series I}

\section{E. Greenland}

Bivalve shells from emerged marine sediments coll by $\mathrm{S}$ Funder and C Hjort during Greenland Geol Survey (GGU) N Greenland Expedition of 1979; subm by C Hjort, Dept Quaternary Geol, Univ Lund. Samples are related to study of glacial history of northeasternmost part of Greenland (Funder and Hjort, 1980). Other samples in series dated in Denmark (Tauber, ms) and UK (AERE Harwell, ms).

Lu-1785. Constable Bugt

$$
\begin{array}{r}
\mathbf{3 9 , 3 0 0}+\mathbf{2 6 0 0} \\
-\mathbf{2 0 0 0} \\
\delta^{19} C=+1.2 \% \text { o }
\end{array}
$$

Shells and fragments (Hiatella arctica) (Sample GGU 223222) from stony silt bed under- and overlain by till, alt $8 \mathrm{~m}$, at Constable Bugt, Johs V Jensen Land (ca $83^{\circ} 36^{\prime} \mathrm{N}, 32^{\circ} 00^{\prime} \mathrm{W}$ ). Comment: outer $46 \%$ removed by acid leaching. (3 1-day counts.)

$$
\begin{array}{r}
35,400+1650 \\
-1350 \\
\delta^{13} C=+0.9 \% \text { o }
\end{array}
$$

Lu-1786. Herlufsholm strand

Shell fragments (Hiatella arctica) (GGU 223261) from silt surface, alt $75 \mathrm{~m}$, at Herlufsholm strand, Peary Land (ca $82^{\circ} 41^{\prime} \mathrm{N}, 22^{\circ} 50^{\prime} \mathrm{W}$ ). Comment: outer $25 \%$ removed by acid leaching. (3 1-day counts.)

$$
\begin{array}{lr} 
& +2250 \\
\mathbf{3 8 , 4 0 0} & -\mathbf{1 7 5 0} \\
\text { Lu-1787. Krogerup Bugt } & \delta^{13} C=+0.5 \% \\
\text { Shells and fragments (Astarte borealis and Mya } & \text { truncata) (GGU } \\
\text { 223263) from bedded sand containing stones, alt } 48 \text { to } 58 \mathrm{~m} \text {, at Krogerup }
\end{array}
$$


Bugt, Peary Land (ca $82^{\circ} 34^{\prime} \mathrm{N}, 20^{\circ} 27^{\prime} \mathrm{W}$ ). Comment: outer $48 \%$ removed by acid leaching.

\section{$\mathbf{3 3 , 7 0 0}$}

Lu-1788. Kap Köbenhavn

$$
\begin{array}{r}
-1050 \\
\delta^{13} C=-0.4 \% \text { o }
\end{array}
$$

Shell fragments (Hiatella arctica and Mya truncata) (GGU 223267) from till bed (Funder and Hjort, 1980, Fig 2, Unit 12) on top of interglacial sequence at Kap Köbenhavn, Peary Land (ca $82^{\circ} 25^{\prime} \mathrm{N}, 20^{\circ} 57^{\prime}$ W). Comment: outer 10\% removed by acid leaching. Innermost $47 \%$ lost during processing.

General Comment: corrections for deviations from $\delta^{13} \mathrm{C}=-25 \%$ PDB are applied also for shell samples. No corrections are made for apparent age of shells of living marine mollusks. Apparent age of recent shells from East Greenland is reported by Hjort (1973) but value given there may now need some revision because of better knowledge of ${ }^{14} \mathrm{C}$ activity during last centuries (Stuiver, 1978, p 271; Olsson, 1980).

\section{S Hochstetter Forland series}

Sediment from lakes at Peters Bugt $\left(75^{\circ} 19^{\prime} \mathrm{N}, 20^{\circ} 03^{\prime} \mathrm{W}\right)$ and $3 \mathrm{~km}$ $\mathrm{W}$ of Ailsa hill $\left(75^{\circ} 19^{\prime} \mathrm{N}, 19^{\circ} 40^{\prime} \mathrm{W}\right)$, S Hochstetter Forland, NE Greenland. Coll by Swedish-Danish Expedition of 1976; subm by S Björck and T Persson, Dept Quaternary Geol, Univ Lund. Bio- and chronostratigraphy described by Björck and Persson (ms). Depths given are below sediment surface. No pretreatment; all samples undersized; diluted. Amount of $\mathrm{CO}_{2}$ from sample is given in Comment below as "\% sample". Burned at $<650^{\circ} \mathrm{C}$ to avoid carbonate pyrolysis.

\section{Peters Bugt S $\phi$}

Alt ca $16 \mathrm{~m}$; size $700 \times 300 \mathrm{~m}$.

\section{Lu-1741. Peters Bugt $S \phi, 118$ to $123 \mathrm{~cm}$}

$7440 \pm 95$ arctica - Cassiope - Dryas - Betula nana + exotic pollen local pollen assemblage zone (p.a.z.) (P2). Comment: 71\% sample.

\section{Lu-1742. Peters Bugt $S \phi, 95$ to $100 \mathrm{~cm}$}

$\mathbf{5 1 4 0} \pm \mathbf{1 3 0}$

Clay gyttja with moss remains. Level corresponds to boundary tween Zone P2 and Salix herbacea-Dryas local p.a.z. (P3). Comment: $35 \%$ sample.

Lu-1743. Peters Bugt $S \phi, 70$ to $75 \mathrm{~cm}$

$4530 \pm 130$

Clay gyttja. Level corresponds to uppermost part of Zone P3. Comment: $31 \%$ sample. 


\section{Lu-1744. Peters Bugt $S \phi, 45$ to $50 \mathrm{~cm}$}

Clay gyttja with moss remains. Level corresponds to lower part of upper half of Salix herbacea-Vaccinium-Cassiope - Oxyria-Caryophyllaceae local p.a.z. (P4). Comment: 19\% sample. (3 1-day counts.)

\section{Lu-1745. Peters Bugt S $\phi, 20$ to $25 \mathrm{~cm}$}

$2390 \pm 120$ Salix herbacea - $S$ arctica-Cyperaceae-Gramineae local p.a.z. (P5). Comment: $20 \%$ sample. (3 1-day counts.)

\section{Ailsa S $\phi$}

Estimated alt between 75 and $100 \mathrm{~m}$; size $800 \times 500 \mathrm{~m}$.

Lu-1746. Ailsa $S \phi, 58.5$ to $63.5 \mathrm{~cm}$

$\mathbf{1 1 , 5 4 0} \pm 135$

Clay with lamina of clay gyttja and moss remains. Level corresponds to lower part of Gramineae - Saxifraga - Caryophyllaceae local p.a.z. (Ala). Comment: $73 \%$ sample.

\section{Lu-1747. Ailsa $S \phi, 46$ to $48 \mathrm{~cm}$}

$9330 \pm 145$ of Ailsa S $\phi$ Barren Interzone. Comment: $50 \%$ sample.

\section{Lu-1748. Ailsa $S \phi, 31$ to $37 \mathrm{~cm}$}

$9540 \pm 115$

Muddy clay. Level corresponds to boundary between Gramineae Caryophyllaceae - Saxifraga - Polypodiaceae local p.a.z. (Alb) and Salix herbacea - S arctica - Cassiope local p.a.z. (A2a). Comment: $71 \%$ sample.

Lu-1749. Ailsa $S \phi, 9$ to $15 \mathrm{~cm}$

$$
\begin{array}{r}
\mathbf{6 1 2 0} \pm \mathbf{9 0} \\
\delta^{1 s} C=-28.1 \% 0
\end{array}
$$

Muddy clay and clay gyttja with moss remains. Level corresponds to lower half of Salix herbacea - S arctia - Cassiope - Dryas - Betula nana local p.a.z. (A2b). Comment: $65 \%$ sample.

\section{Woryty series}

\section{F. Poland}

Wood and peat from cores in ancient lake, now overgrown with Carex-fen, at Woryty near Gietrzwałd, Olsztyn Lakeland, NE Poland $\left(53^{\circ} 45^{\prime} \mathrm{N}, 20^{\circ} 10^{\prime} \mathrm{E}\right)$. Coll 1979 by G Digerfeldt and M Ralska-Jasiewiczowa; subm by M Ralska-Jasiewiczowa, Inst Botany, Polish Acad Sci, Kraków. Lu-1789 received mild pretreatment with $\mathrm{NaOH}$ and $\mathrm{HCl}$; all other samples only pretreated with $\mathrm{HCl}$.

\section{Lu-1789. Woryty 80s/IV +80 s/IX}

$10,850 \pm 100$

Wood from 9.77 to $9.82 \mathrm{~m}$ in Core IV and wood and peat from 9.825 to $9.86 \mathrm{~m}$ in Core IX. Both sub-samples are from same stratigraphic posi- 
tion in bottom part of peat layer underlain by sand with gravel and overlain by gyttja.

Lu-1790. Woryty 80s/IV +80 s/VII

$11,290 \pm 105$

Swamp peat from upper part of same peat layer as Lu-1789; from 9.71 to $9.76 \mathrm{~m}$ in Core IV and from 9.6 to $9.85 \mathrm{~m}$ in Core VII.

Lu-1791. Woryty 80s/VI + 80s/VIII

$10,770 \pm 100$

Small pieces of wood from gyttja with high iron sulphide content ca 10 to $15 \mathrm{~cm}$ above transition peat/gyttja. Sub-samples are from 9.62 to $9.68 \mathrm{~m}$ in Core VI and from 9.6 to $9.65 \mathrm{~m}$ in Core VIII.

\section{Lu-1792. Woryty 80s/IX, Sample I}

$11,020 \pm 110$

Small pieces of wood from transition peat/gyttja in four different cores and peat from same transition at 9.64 to $9.67 \mathrm{~m}$ in Core IX.

\section{Lu-1793. Woryty 80s/IX, Sample 2}

$10,900 \pm 120$ Sample is from peat layer not found in other cor and separated from peat/gyttja transition dated as Lu-1792 by another iron sulphide at 9.86 to $9.94 \mathrm{~m}$. Comment: sample undersized; diluted; $76 \%$ sample.

\section{G. Switzerland}

\section{Lu-1723. Veyrier}

$13,000 \pm 120$

$\boldsymbol{\delta}^{13} \mathrm{C}=-26.3 \%$ Basin $\left(46^{\circ} 09^{\prime}\right.$ landslide material below Saleve Mt near Veyrier, Geneva Basin $\left(6^{\circ} 09^{\prime} \mathrm{N}, 6^{\circ} 12^{\prime} \mathrm{E}\right)$. Coll 1979 and subm by $\mathrm{C}$ Reynaud, Inst Geol, Geneva. Landslide material underlain by lacustrine deposits rich in pollen. Assoc with mammoth bone and reindeer antler artifacts, indicating Magdalenian culture.

\section{Lu-1761. Lully}

$6650 \pm 65$

Wood from old fluvial meander at Lully, Geneva Basin (ca $46^{\circ} 10^{\prime}$ N, $6^{\circ} 04^{\prime}$ E). Coll 1979 by G F Amberger, Geol Survey, Canton Geneva; subm by $\mathrm{G}$ F Amberger and $\mathrm{C}$ Reynaud. Comment: mild pretreatment with $\mathrm{NaOH}$ and $\mathrm{HCl}$. A second preparation including complete removal of lignin fraction was dated at $6590 \pm 90$ in agreement with lst result.

\section{H. Mexico}

\section{Lagunillas San Pedro series}

Sediment from Lagunillas San Pedro, S of Tepic, Prov Nayarit, NW Mexico $\left(21^{\circ} 10^{\prime} \mathrm{N}, 104^{\circ} 40^{\prime} \mathrm{W}\right)$. Coll 1979 and subm by R B Brown and V Markgraf, Dept Geosci, Univ Arizona, Tucson. Pretreated with HCl. Burned at $<650^{\circ} \mathrm{C}$ to avoid oxidation of graphite. 
Lu-1729. San Pedro, 101 to $102 \mathrm{~cm}$ $\mathbf{3 6 0} \pm \mathbf{5 0}$

Brown silt. Comment: sample undersized; diluted; $84 \%$ sample.

$$
\delta^{13} \mathrm{C}=-18.3 \%
$$

Lu-1730. San Pedro, 150 to $151 \mathrm{~cm}$

$\mathbf{7 2 0} \pm \mathbf{5 0}$

Brown silt.

$\delta^{13} C=-17.9 \%$

Lu-1731. San Pedro, 250 to $251 \mathrm{~cm}$

$1820 \pm 60$

Dark brown sandy clay. Comment: sample undersized. diluted. $68 \%$ sample.

\section{San Nicolas de Parangeo series}

Soil samples from San Nicolas de Parangeo, Valle de Santiago, Guanajuato, NW Mexico (ca $21^{\circ} \mathrm{N}, 101^{\circ} 15^{\prime} \mathrm{W}$ ). Coll Aug 1978 by R B Brown; subm by R B Brown and V Markgraf. No pretreatment because of low organic carbon content. Burned at $<650^{\circ} \mathrm{C}$ to avoid pyrolysis of carbonate and oxidation of graphite.

\section{Lu-1733. San Nicolas, Samples 25A-467}

$310 \pm 75$ diluted; $43 \%$ sample.

Lu-1733C. San Nicolas (25A-467), carbonate $\begin{array}{r}\mathbf{3 3 6 0} \pm \mathbf{1 7 5} \\ \boldsymbol{\delta}^{13} C=+3.5 \%\end{array}$

Carbonate fraction extracted from ash residue of Sample Lu-1733 after burning. Comment: undersized; diluted; $28 \%$ sample. (1 1-day count.)

\section{Lu-1734. San Nicolas, Sample 25B-489}

$\mathbf{2 7 0 0} \pm \mathbf{8 0}$

Soil from 489 to $491 \mathrm{~cm}$. Comment: undersized; diluted; $50 \%$ sample.

Lu-1734C. San Nicolas (25B-489), carbonate $\begin{array}{r}4360 \pm 150 \\ \delta^{1 s} C=+3.8 \%\end{array}$

Carbonate fraction extracted from ash residue of Sample Lu-1734 after burning. Comment: undersized; diluted; $25 \%$ sample.

\section{PLANT ECOLOGY SAMPLES}

For some samples, results are given as difference, $\Delta$, from our radiocarbon standard $(95 \%$ activity of NBS oxalic acid standard, age corrected to 1950$)$ :

$$
\Delta=\delta^{14} \mathrm{C}-\left(2 \delta^{13} \mathrm{C}+50\right)\left(1+\frac{\delta^{14} \mathrm{C}}{1000}\right)
$$

where $\delta^{14} \mathrm{C}$ is observed deviation from radiocarbon standard in per mil and $\delta^{13} \mathrm{C}$ deviation from PDB standard in per mil.

\section{Stordalenmyren series}

Peat and wood from peat bog Stordalenmyren, $1.5 \mathrm{~km}$ NNW of Stordalen RR Sta, N Sweden (68 $22^{\prime}$ N, $19^{\circ} 03^{\prime}$ E). Coll Aug 1979 and subm 
by N Malmer, Dept Plant Ecology, Univ Lund. Depths given refer to bog surface.

$$
\begin{array}{r}
\text { Lu-1816. Stordalenmyren I, } 38 \text { to } 43 \mathrm{~cm} \quad \Delta=-\mathbf{5 . 8} \pm \mathbf{5 . 5} \% \\
\boldsymbol{\delta}^{13} C=-25.8 \% \text { o }
\end{array}
$$

Slightly humified Sphagnum peat from 38 to $43 \mathrm{~cm}$, Profile I, without admixture of mineral soil and underlain by peat with such admixture. Comment: normal pretreatment with $\mathrm{HCl}$ and $\mathrm{NaOH}$.

\section{$\Delta=-21.3 \pm 5.4 \%$ $\delta^{13} C=-26.6 \%$}

Slightly humified Sphagnum peat from 43 to $45 \mathrm{~cm}$, Profile I, with admixture of mineral soil, underlain by slightly humified Sphagnum balticum peat. Comment: mild pretreatment with $\mathrm{HCl}$ and $\mathrm{NaOH}$.

\section{Lu-1818. Stordalenmyren II, wood}

$$
\begin{aligned}
\Delta= & +\mathbf{3 1 . 0} \pm \mathbf{8 . 1} \% o \\
& \delta^{13} C=-28.3 \% o
\end{aligned}
$$

Wood (Betula nana, id by N Malmer) in horizontal position, depth $20 \mathrm{~cm}$, Profile II, ca $300 \mathrm{~m} \mathrm{~W}$ of Profile I, in slightly humified peat with Sphagnum and Dicranum elongatum. Comment: no pretreatment; small sample; diluted; $50 \%$ sample. $\Delta$ value corresponds approx to increase in activity of annual plants grown in summer of 1956.

\section{Lu-1820. Stordalenmyren II 50 to $500 \pm \mathbf{5 0}$}

Slightly humifed Sphagnum peat with some Carex remains, from 50 to $54 \mathrm{~cm}$, Profile II, directly above perma-frost. Comment: normal pretreatment with $\mathrm{HCl}$ and $\mathrm{NaOH}$.

\section{Getamossen, Roshult series}

Peat and other plant remains from peat bog Getamossen, $1 \mathrm{~km}$ SSW of Roshult, Breared parish, Halland (56 $\left.46^{\circ} 1^{\prime} \mathrm{N}, 13^{\circ} 13^{\prime} \mathrm{E}\right)$. Coll Oct 1979 and subm by N Malmer. Geology, botany, and hydrology of bog described by Olausson (1957). Depths refer to bog surface. Lu-1821 received mild pretreatment with $\mathrm{NaOH}$ and $\mathrm{HCl}$. Two other samples were too small to allow pretreatment.

Le21. $\mathbf{8 0 0} \pm \mathbf{5 0}$
$=-25.6 \%$ Moderately humified Sphagnum peat from 60 to $62 \mathrm{~cm}$, Profile VI.

Lu-1822. Getamossen VI, Roshult, $37 \mathrm{~cm}$ $70 \pm 45$

$$
\begin{array}{r}
\Delta=-\mathbf{8 . 9} \pm \mathbf{5 . 5} \% \text { o } \\
\delta^{1 s} C=-24.5 \% \text { o }
\end{array}
$$

Basal sheaths of Eriophorum vaginatum, depth $37 \mathrm{~cm}$ in slightly humified Sphagnum peat, Profile VI. 
Lu-1823. Getamossen VII, Roshult, 58cm $\quad \delta^{13} C=-22.1 \%$

Basal sheaths of Eriophorum vaginatum, depth $58 \mathrm{~cm}$ in slightly humified Sphagnum peat, Profile VII. Comment: sample undersized; diluted; $78 \%$ sample.

\section{Lu-1824. Åkhultmyren}

$$
\begin{array}{r}
\Delta=+\mathbf{7 0 . 3} \pm \mathbf{7 . 1} \% \\
\delta^{13} \mathrm{C}=-23.4 \% \text { \% }
\end{array}
$$

Basal sheaths of Eriophorum vaginatum, depth 40 to $44 \mathrm{~cm}$ in Sphagnum peat, Profile IX from bog Akhultmyren, $0.9 \mathrm{~km}$ NNE of Akhult village, Moheda parish, Småland $\left(57^{\circ} 06^{\prime} \mathrm{N}, 14^{\circ} 33^{\prime} \mathrm{E}\right)$. Coll Oct 1979 and subm by $\mathrm{N}$ Malmer. Comment: no pretreatment; small sample; diluted; $65 \%$ sample. $\Delta$ value corresponds approx to increase in activity of annual plants grown in spring of 1957.

\section{ARCHAEOLOGIC SAMPLES}

\section{Hötofta series}

\section{A. Sweden}

Charcoal from Iron age settlement area at Hötofta $2^{1}$, S §̊arp parish, SW Scania $\left(55^{\circ} 30^{\prime} \mathrm{N}, 13^{\circ} 05^{\prime} \mathrm{E}\right)$. Coll 1977-1978 by A Nilsson; subm by B Stjernquist, Hist Mus, Univ Lund. Dated as complement to earlier study by submitter (Stjernquist, 1969). Pretreated with $\mathrm{HCl}$ and $\mathrm{NaOH}$.

\section{Lu-1687. Hötofta 21, Sample 1}

$\mathbf{9 9 0} \pm \mathbf{5 0}$

Charcoal from cultural layer. Assoc with potsherds.

$$
\delta^{13} C=-24.2 \%
$$

Lu-1688. Hötofta $2^{1}$, Sample 2

$\mathbf{1 0 3 0} \pm \mathbf{5 0}$

Charcoal from oven in remnants of pit-house. Assoc with potsherds.

Lu-1689. Hötofta 2 ${ }^{1}$, Sample 3

$1180 \pm 50$

Charcoal from hearth at base of remnants of Pit-house 1:1977.

Lu-1690. Hötofta 2 ${ }^{1}$, Sample 4

$\mathbf{1 2 0 0} \pm \mathbf{5 0}$

Charcoal from Hearth A assoc with remnants of Pit-house 3:1977.

Lu-1691. Hötofta $2^{1}$, Sample 5

$1100 \pm 50$

Charcoal from clay layer in burned house. Position 36-37.

General Comment (BS): dates of importance for settlement chronology in area.

Lu-1828. Näbbe mosse

$4920 \pm 60$

Collagen from fragmentary human ulna and humerus (No. LUHM 28787) from Näbbe mosse, Ö Wemmerlöv parish, Scania $\left(55^{\circ} 36^{\prime} \mathrm{N}, 14^{\circ}\right.$ $36^{\prime}$ E). Coll 1948 and subm by B Stjernquist. Assoc with upper part of 
human skull and 2 worked implements of red deer bone. Site and finds described by Stjernquist, Nilsson, and Nybelin (1953). Comment: organic carbon content: $6.8 \%$. Date somewhat later than expected. In same areas several artifacts from early Neolithic period were found.

\section{Ingelstorp series}

Charcoal from Early Iron age grave field at Ingelstorp, Scania. Coll 1975-1977 and subm by M Strömberg, Hist Mus, Univ Lund. Preliminary report pub by submitter (Strömberg, 1977). For other dates from Ingelstorp, see R, 1976, v 18, p 314; 1977, v 19, p 435-436; 1978, v 20, p $430-432 ; 1980, \mathrm{v} 22$, p 1061 . Lu-1710 received mild pretreatment with $\mathrm{NaOH}$ and $\mathrm{HCl}$; all other samples were too small to allow pretreatment.

Lu-1709. Ingelstorp $31: 6$, Sample $7: 78-79 \quad \delta^{1 s} C=-24.2 \%$

Charcoal from fire pit, Grave 23, Field 1, Ingelstorp 31:6 $\left(55^{\circ} 25^{\prime}\right.$ $\mathrm{N}, 14^{\circ} 03^{\prime} \mathrm{E}$ ). Assoc with burned bones and potsherds. Comment: sample undersized; diluted; $91 \%$ sample.

Lu-1711. Ingelstorp 31 :6, Sample 9:78-79 $\delta^{13} C=-24.5 \%$

Charcoal from fire pit, Grave 24, Field 1. Assoc with pottery and burned bones. Comment: sample undersized; diluted; $60 \%$ sample.

Lu-1708. Ingelstorp 32, Sample 6:78-79 $\delta^{13} C=-23.8 \%$

Charcoal from fire pit, Grave 44, Field 4, Ingelstorp $32\left(55^{\circ} 25^{\prime} \mathrm{N}\right.$, $14^{\circ} 04^{\prime}$ E). Assoc with burned bones and potsherds. Comment: sample undersized; diluted; $91 \%$ sample.

Lu-1710. Ingelstorp 32, Sample 8:78-79

$2560 \pm 55$

Charcoal from fire pit, Grave 30, Field 4. Assoc with burned bones.

Lu-1713. Ingelstorp 32, Sample 11:78-79

$\mathbf{2 7 1 0} \pm \mathbf{8 5}$

Charcoal from fire pit, Grave 55, Field 4. Assoc with 2 flint objects and burned bones of human male and dog. Comment: sample undersized; diluted; $46 \%$ sample.

\section{Lu-1714. Valleberga 194: 1, Sample 12:78-79 $\delta^{13} \mathrm{C}=-22$.}

$\mathbf{2 1 5 0} \pm \mathbf{5 0}$

Charcoal from hearth in House 1:1979 in settlement area at Valleberga 194:1, Scania $\left(55^{\circ} 24^{\prime} \mathrm{N}, 14^{\circ} 05^{\prime} \mathrm{E}\right)$. Property designation is $4: 2 \mathrm{~A}$ on older map. Coll 1979 and subm by M Strömberg. Assoc with pottery, spindle whorls, and iron objects indicating Late Iron age. Mild pretreatment with $\mathrm{NaOH}$ and $\mathrm{HCl}$.

\section{Lu-1715. Ageröds mosse, human skull}

$\mathbf{2 2 9 0} \pm \mathbf{5 5}$ Ageröds mosse, Munkarp parish, Scania (ca $55^{\circ} 56.5^{\prime} \mathrm{N}, 13^{\circ} 25^{\prime} \mathrm{E}$ ). Coll 
1918; subm by L Larsson, Hist Mus, Univ Lund. Collagen extracted as described previously ( $R, 1976, \mathrm{v} 18$, p 290), including $\mathrm{NaOH}$ treatment. Organic carbon content: $4.2 \%$.

\section{Ängdala series (II)}

Charcoal from Neolithic flint mines in Senonian chalk at Ängdala, S Sallerup parish, Scania $\left(55^{\circ} 35^{\prime} 20^{\prime \prime} \mathrm{N}, 13^{\circ} 07^{\prime} 20^{\prime \prime} \mathrm{E}\right)$. Coll 1979 by U Säfvestad; subm by B Salomonsson, Malmö Mus. Dated as complement to Ängdala series (R, 1980, v 22, p 1058).

Lu-1779. Ängdala 1979, Structures 15 and $23 \quad \begin{array}{r}4970 \pm 65 \\ \delta^{13} C=-23.3 \%\end{array}$ Charcoal from flint mines. Comment: pretreated with $\mathrm{HCl}$.

\section{Lu-1780. Ängdala 1979, Structure $21 \quad \delta^{13} C=-24.6 \%$}

Charcoal from test trench. Comment: pretreated with $\mathrm{HCl}$ and $\mathrm{NaOH}$. Sample undersized; diluted; $42 \%$ sample.

\section{Yngsjö Series I}

Charcoal samples from coastal settlement area at Yngsjö 1:167, Åhus parish, Scania $\left(55^{\circ} 54^{\prime} 44^{\prime \prime} \mathrm{N}, 14^{\circ} 16^{\prime} 29^{\prime \prime} \mathrm{E}\right)$. Alt 3.4 to $3.8 \mathrm{~m}$. Coll 1979 and subm by $\mathrm{J}$ Callmer, Hist Mus, Univ Lund.

\section{Lu-1803. Yngsjö 1:167, Sample 1:79}

$\mathbf{2 5 0 0} \pm \mathbf{5 5}$

Charcoal from hearth (120-134) below thin cultural layer containing mixed material from Middle Neolithic, Late Neolithic, and 8th century AD. Comment: pretreated with $\mathrm{NaOH}$ and $\mathrm{HCl}$.

\section{Lu-1804. Yngsjö 1:167, Sample 2:79}

$$
\begin{array}{r}
\mathbf{2 6 7 0} \pm \mathbf{5 5} \\
\delta^{13} C=-23.6 \% 0
\end{array}
$$

Charcoal from hearth $(124 / 125-140)$ in about same stratigraphic position as Lu-1803, below thin cultural layer. Comment: pretreated with $\mathrm{NaOH}$ and $\mathrm{HCl}$.

\section{Lu-1805. Yngsjö 1:167, Sample $3: 79$}

$1690 \pm 55$

$\delta^{13} C=-24.8 \%$

Charcoal from Structure 3, Surface 2 (141-160). Assoc with debris from glass workshop indicating Late Iron age. Comment: pretreated with $\mathrm{NaOH}$ and HCl. Sample undersized; diluted; $87 \%$ sample.

\section{Lu-1806. Yngsjö 1:167, Sample 4:79}

$$
1600 \text { 上 } 85
$$

Charcoal from Structure 5 (140-175). Assoc with debris from glass workshop. Comment: no pretreatment; undersized; diluted; $42 \%$ sample. Burned at $<650^{\circ} \mathrm{C}$ to avoid pyrolysis of carbonate.

\section{Lu-1807. Yngsjö 1:167, Sample 5:79}

$2420 \pm 65$

Charcoal from hearth (140-200) in about same stratigraphic position as Lu-1803 and Lu-1804, below thin cultural layer. Comment: no pretreat- 
ment; undersized; diluted; $52 \%$ sample. Burned at $<650^{\circ} \mathrm{C}$ to avoid pyrolysis of carbonate.

\section{Carrowmore Series I}

\section{B. Ireland}

Charcoal, soot, peat, wood, and mollusk shells from Megalithic cemetery $\left(54^{\circ} 15^{\prime} \mathrm{N}, 8^{\circ} 32^{\prime} \mathrm{W}\right)$ and settlement remains at the Carrowmore area, Co Sligo, Ireland. Coll $1977-80$ and subm by G Burenhult, Hist Mus, Univ Lund and Inst Archaeol, Univ Stockholm. Results of 3 excavation seasons reported by submitter (Burenhult, 1980).

\section{Lu-1441. Carrowmore, Grave 7}

$$
\mathbf{5 2 4 0} \pm \mathbf{8 0}
$$

Charcoal from intact basal layer in central chamber, Grave 7 (Buren hult, 1980, p 19-32). Coll Aug 1977. Comment: mild pretreatment with $\mathrm{NaOH}$ and $\mathrm{HCl}$.

\section{Lu-1442. Carrowmore, Test-hole 88}

$$
600 \pm 45
$$

Two upper shells of Ostrea edulis from bottom of Test-hole 88 assoc with Grave 7. Comment: correction for deviation from $\delta^{13} \mathrm{C}=-25 \%$ PDB is applied also for this sample. No correction is made for apparent age of living marine mollusks.

Lu-1584. Carrowmore, Grave 26, Sample A $\quad \begin{array}{r}\mathbf{2 4 8 0} \pm \mathbf{5 5} \\ \delta^{13} C=-24.8 \% \circ\end{array}$

Charcoal from bottom of ritual Pit 3, Grave 26 (Burenhult, 1980, fig 9, p 41; fig 10, p 42). Comment: pretreated with $\mathrm{HCl}$ and $\mathrm{NaOH}$.

Lu-1585. Carrowmore, Grave 26, Sample B $\quad \delta^{13} C=-26.3 \%$ Charcoal from ritual Pit 5, Grave 26 (Burenhult, 1980, fig 10, p 42; fig 13, p 46). Comment: pretreated with $\mathrm{HCl}$ and $\mathrm{NaOH}$.

Lu-1586. Carrowmore, Grave 26, Sample C $\quad \begin{array}{r}\mathbf{2 4 4 0} \pm \mathbf{5 5} \\ \delta^{13} C=-26.2 \% \text { o }\end{array}$

Charcoal from bottom of inner part of ritual Pit 5, under ditch, Grave 26 (Burenhult, 1980, fig 10, p 42; fig 13, p 46). Comment: pretreated with $\mathrm{HCl}$ and $\mathrm{NaOH}$.

141624. Carrowmore, Grave 26, Sample 2:A $\quad \begin{array}{r}\mathbf{2 4 8 0} \pm \mathbf{5 5} \\ \delta^{13} C=-24.6 \%\end{array}$

Charcoal from bottom of ditch, Grave 26 (Burenhult, 1980, fig 10, p 42; fig 15, p 49). Comment: mild pretreatment with $\mathrm{NaOH}$ and $\mathrm{HCl}$.

Lu-1625. Carrowmore, Grave 26, Sample $3 \quad \begin{array}{r}2540 \pm 60 \\ \delta^{13} C=-25.4 \%\end{array}$

Charcoal from stone-packing at entrance of Grave 26 (Burenhult, 1980, fig 10, p 42). Comment: mild pretreatment with $\mathrm{NaOH}$ and $\mathrm{HCl}$. Sample undersized; diluted; $87 \%$ sample. 
Lu-1626. Carrowmore, Grave 26, Sample $1: \mathbf{A}^{2} \quad \delta^{13} C=-23.0 \%$ o

Charcoal from burned post, ritual Pit 2, Grave 26 (Burenhult, 1980, fig 10, p 42; fig 12, p 45). Comment: pretreated with $\mathrm{HCl}$ and $\mathrm{NaOH}$.

$2630 \pm 55$

Lu-1627. Carrowmore, Grave 26, Sample $1: B \quad \delta^{13} C=-2 \overline{3} .6 \%$ o

Charcoal from ritual Pit 1, Post-hole 2, Grave 26 (Burenhult, 1980, fig 10, p 42; fig 12, p 45). Comment: mild pretreatment with $\mathrm{NaOH}$ and $\mathrm{HCl}$.

Lu-1628. Carrowmore, Grave 26, Sample $5 \quad \begin{aligned} & 1860 \pm 110 \\ & \delta^{13} C=-23.8 \% \text { o }\end{aligned}$

Charcoal from Pit 4, Grave 26. Comment: no pretreatment; small sample; diluted; $30 \%$ sample.

Lu-1630. Carrowmore, Grave 27, Sample A-78 $\delta^{13} C=-23.8 \%$ o

Charcoal from intrusion in chamber, Grave 27 (Burenhult, 1980, fig 23, p 62) Comment: no pretreatment; small sample; diluted; $55 \%$ sample.

Lu-1631. Carrowmore, Grave 27, Sample B-78 $\delta^{13} C=-24.8 \%$ o

Charcoal from intrusion in chamber, Grave 27 (Burenhult, 1980, fig 20, p 60). Comment: no pretreatment; small sample; diluted; $49 \%$ sample.

Lu-1698. Carrowmore, Grave 27, Sample 4-79 $\delta^{1 s} C=-22.9 \%$

Charcoal from inner stone-packing, Grave 27 (Burenhult, 1980, fig 20, p 60). Comment: pretreated with $\mathrm{HCl}$ and $\mathrm{NaOH}$.

Lu-1750. Carrowmore, Grave 4, Sample $2 \quad \delta^{13} C=-24.3 \%$

Charcoal from inner stone-packing, Grave 4. Comment: no pretreatment; small sample; diluted; $50 \%$ sample. (3 1-day counts.)

1752. $1520 \pm 50$

Charcol from lower layer, Structure 2 phosphate Test 36 , Carrowmore (Burenhult, 1980, p 105). Comment: mild pretreatment with $\mathrm{NaOH}$ and $\mathrm{HCl}$.

Lu-1699. Grange West, Settlement 2, Sample B $\delta^{13} C=-24.1 \%$ o

Charcoal from Settlement 2 (Burenhult, 1980, p 100), phosphate Test 21, Grange West $\left(54^{\circ} 15^{\prime} \mathrm{N}, 8^{\circ} 35^{\prime} \mathrm{W}\right)$. Comment: no pretreatment; small sample. Lu-1753. Grange West, Settlement 1, Sample A $\begin{array}{r}\mathbf{1 1 6 0} \pm \mathbf{5 0} \\ \delta^{13} C=-24.5 \%\end{array}$

Charcoal from Settlement 1 (Burenhult, 1980, p 100), phosphate Test 24. Comment: mild pretreatment with $\mathrm{HCl}$ and $\mathrm{NaOH}$. 
Lu-1754. Grange West, Settlement 1, Sample Al

$1010 \pm 50$

$\delta^{13} C=-24.4 \%$ o

Charcoal from Settlement 1, phosphate Test 23. Comment: small sample; diluted; $88 \%$ sample. No pretreatment.

Lu-1755. Grange West, Settlement 3, Sample C $\begin{array}{r}1990 \pm 50 \\ \delta^{13} C=-23.7 \% \text { 。 }\end{array}$

Charcoal from Settlement 3, phosphate Test 3B. Comment: no pretreatment; small sample.

Lu-1756. Grange West, Settlement 8, Sample D $\delta^{13} C=-24.1 \%$

Charcoal from Settlement 8, phosphate Test 16. Comment: pretreated with $\mathrm{HCl}$ and $\mathrm{NaOH}$.

Lu-1757. Grange West, Settlement 11, $\quad 1310 \pm 50$ Sample E

$\delta^{18} C=-24.5 \%$

Charcoal from Settlement 11, phosphate Test 11B. Comment: mild pretreatment with $\mathrm{HCl}$ and $\mathrm{NaOH}$.

$1230 \pm \mathbf{5 0}$
$C=-24.4 \%$

Lu-1758. Grange West, Settlement 6, Sample G $\delta^{13} C=-24.4 \%$
Charcoal from Settlement 6, phosphate Test 3. Comment: mild pretreatment with $\mathrm{HCl}$ and $\mathrm{NaOH}$.

\section{Lu-1759. Culleenamore, Settlement 15,} Sample H

$$
\begin{array}{r}
\mathbf{3 7 8 0} \pm \mathbf{6 0} \\
\delta^{13} C=-24.8 \% \text { o }
\end{array}
$$

Charcoal from lower layer of kitchen midden, Settlement 15, Culleenamore (Burenhult, 1980, p 91). Comment: pretreated with $\mathrm{HCl}$ and $\mathrm{NaOH}$.

Lu-1808. Carrowmore, Grave 27, Sample 1-79 $\delta^{13} C=-23.7 \%$

Charcoal from inner stone-packing, Grave 27 (Burenhult, 1980, fig 20, p 60; p 67). Comment: mild pretreatment with $\mathrm{NaOH}$ and $\mathrm{HCl}$.

Lu-1810. Carrowmore $4940 \pm 85$

$\begin{array}{lll}\text { Charcol from } & \delta^{13} \mathrm{C}=-23.4 \% 0\end{array}$ treatment; small sample; diluted; $48 \%$ sample. (3 1-day counts.)

Lu-1811. Carrowmore, Grave 4, Sample 1

$1690 \pm 55$

Burned animal bones from central ch 1980, fig 27, p 80). Comment: no pretreatment.

\section{Lu-1809. Luffertan, Field IX}

$9440 \pm 100$

Charcoal from Luffertan $\left(54^{\circ} 15^{\prime} \mathrm{N}, 8^{\circ} 32^{\prime} \mathrm{W}\right)$, Field IX, phosphate Test 97 (Burenhult, 1980, p 102; map 17, p 105). Comment: no pretreatment: small sample; diluted; $86 \%$ sample. 
Lu-1838. Grange West 1980, Settlement 2

$$
1320 \pm 70
$$

Charcoal from under original stone-packing, Settlement 2, phosphate Test 5. Comment: mild pretreatment with $\mathrm{NaOH}$ and HCl. Small sample; diluted; $56 \%$ sample.

Lu-1839. Knocknarea 1980, Hut Site 2

$$
\begin{array}{r}
\mathbf{2 7 7 0} \pm \mathbf{5 5} \\
\delta^{13} C=-28.0 \% \text { o }
\end{array}
$$

Highly humified peat with soot and small charcoal fragments from hearth at Knocknarea $\left(54^{\circ} 15^{\prime} \mathrm{N}, 8^{\circ} 35^{\prime} \mathrm{W}\right)$, Hut Site 2, Test 1. Comment: pretreated with HCl. $\mathbf{5 7 5 0} \pm \mathbf{8 5}$
$=-30.2 \%$

Sooty mineral soil from basal layer, central chamber, Grave 4 , x -1.25 ; y \pm 0.00 . Comment: pretreated with $\mathrm{HCl}$ and $\mathrm{NaOH}$. Sample undersized; diulted; $71 \%$ sample.

Lu-1841. Cloverhill Lough 1980, Sample $5 \quad \begin{array}{lr}1120 \pm 50 \\ \delta^{13} C=-26.2 \%\end{array}$

Small wood pieces from floor of crannog, Layer VIIIA, phosphate Test 26, Cloverhill Lough $\left(54^{\circ} 15^{\prime} \mathrm{N}, 8^{\circ} 32^{\prime} \mathrm{W}\right)$. Comment: no pretreatment; small sample.

General Comment: eight samples, too small to allow pretreatment, were burned at $<650^{\circ} \mathrm{C}$ in order to avoid pyrolysis of carbonates (Lu-1628, $-1630,-1631,-1699,-1754,-1809$ to -1811$)$.

\section{Ambelikou series}

$$
\text { C. Cyprus }
$$

Charcoal from Ambelikou, Aletri, Cyprus (35 $12^{\prime} \mathrm{N}, 32^{\circ} 45^{\prime} \mathrm{E}$ ). Coll 1942 by P Dikaios; subm by E Gjerstad, Dept of Classical Studies, Univ Lund. Pretreated with $\mathrm{HCl}$ and $\mathrm{NaOH}$.

\section{Lu-1694. Ambelikou, Sample 1}

$3660 \pm 55$

Charcoal from Area 2. Assoc with pottery from Early Cypriote III of Bronze age and copper slag.

\section{Lu-1726. Ambelikou, Sample 2}

Charcoal from mine gallery.

$$
\begin{array}{r}
\mathbf{3 6 3 0} \pm \mathbf{5 5} \\
\delta^{13} C=-22.9 \% \text { o }
\end{array}
$$

\section{Lu-1695. Kythrea, Cyprus}

$$
4410 \pm 60
$$

$\delta^{13} \mathrm{C}=-22.4 \%$

Charcoal from Level IV, $\Delta$ 12, Kythrea, Cyprus (ca $35^{\circ} 20^{\prime} \mathrm{N}, 33^{\circ} 30^{\prime}$ E). Coll 1930 by A Westholm; subm by E Gjerstad. Assoc with pottery, flint tools, stone axes, mortars, and grinding stones, and deer horn fragments, indicating Late Stone age. Comment: pretreated with HCl. 


\section{REFFRENCES}

Berglund, B E, ed, 1979, Palaeohydrological changes in the temperate zone in the last 15,000 years. Subproject B. Lake and mire environments: Project Guide I, Dept Quaternary Geol, Univ Lund, $123+21$ p.

Burenhult, Göran, 1980, The archaeological excavation at Carrowmore, Co Sligo, Ireland. Excavation seasons 1977-79: Theses and papers in North-European Archacol 9, Inst Archacol, Univ Stockholm, 143 p.

Funder, S and Hjort, C, 1980, A reconnaissance of the Quaternary Geology of Eastern North Greenland: Rapp Grönland Geol Unders, v 99, p 99-105.

Håkansson, Sören, 1968, University of Lund radiocarbon dates I: Radiocarbon, v 10, p 36-54.

$330 . \quad 1974$, University of Lund radiocarbon dates VII: Radiocarbon, v 16, p 307 $290-320$.

1976, University of Lund radiocarbon dates IX: Radiocarbon, v 18, p

1977, University of Lund radiocarbon dates X: Radiocarbon, v 19, p 424-441 1978, University of Lund radiocarbon dates XI: Radiocarbon, v 20, p 416435 . 384-404.

1979, University of Lund radiocarbon dates XII: Radiocarbon, v 21, p

1980, University of Lund radiocarbon dates XIII: Radiocarbon, v 22, p $1045-1063$

Hjort, Christian, 1973, A sea correction for East Greenland: Geol Fören Stockholm Förh, v 95, p 132-134.

Mikaelsson, Jan, 1978, Strandvallskomplexet vid Olsäng: Blekinges Natur 1978 (Karlskrona), p 37-52.

Olausson, E, 1957, Das Moor Roshultsmyren. Eine geologische, botanische und hydrologische Studie in einem Südwestschwedischen Moor mit excentrisch gewölbten Mooselementen: Lunds Univ Årsskr, NF, Avd 2, v 53, no. 12, 72 p.

Olsson, I U, 1980, Content of ${ }^{14} \mathrm{C}$ in marine mammals from northern Europe, in Stuiver, Minze and Kra, Renee, eds, Internatl radiocarbon conf, 10th, Proc: Radiocarbon, v 22, no. 3, p 662-675.

Stjernquist, B, 1969, En boplats från äldre järnålder i Hötofta, sydvästra Skåne: Fornvännen, no. 3, 1969, p 161-179.

Stjernquist, B, Nilsson, T, and Nybelin, O, 1953, Some Stone age fishing tackle from Scania: Kungl Humanistiska Vetensskapssamfundets i Lund Årsberättelse 1952 1953, p 123-148.

Strömberg, M, 1977, Bondesamhällen under Ingelstorps forntid: Kulturnämnden i Ystad 1977, $84 \mathrm{p}$.

Stuiver, Minze, 1978, Radiocarbon timescale tested against magnetic and other dating methods: Nature, v 273, p 271-274. 